\author{
ISSN: 2146-3042 \\ DOI: $10.25095 /$ mufad.510605
}

\title{
Zamana Dayalı Faaliyet Tabanlı Maliyetleme ve Bir Uygulama*
}

\author{
Mahmut Sami ÖZTÜRK ** \\ Saif ALSAMARRAI ${ }^{* * *}$
}

\begin{abstract}
$\ddot{O Z Z E T}$
Bu çalışmada, çağdaş maliyetleme sistemlerinden biri olan Zamana Dayalı Faaliyet Tabanlı Maliyetleme (ZDFTM) sistemi, ilaç üretimi yapan bir firmada uygulanmaktadır. Firma genel üretim maliyetlerini geleneksel yöntemlere göre dağıtmakta ve mamul maliyetlerini doğru bir biçimde hesaplayamamaktadır. Dolayısıyla bu çalışmanın amacı, mamul maliyetlerinin daha doğru bir şekilde hesaplanmasını sağlayan çağdaş maliyetleme sistemlerinden olan ZDFTM yönteminin firmada uygulanabilirliğinin araştırılmasıdır. Ayrıca çalışmada, mamullere düșen genel üretim gideri payının tespit edilmesi ve ulaşılan sonuçlar ile firmanın mevcut maliyet hesaplama sonuçlarının karşılaștırılması hedeflenmektedir. Bu amaç doğrultusunda ZDFTM sisteminin uygulanması konusunda fabrika içerisinde gözlemlemeler yapılarak ve fabrikadaki yöneticiler ile görüşmeler gerçekleştirilerek, gerekli verilere ulaşılmıştır. Elde edilen veriler ile sistemin uygulanması gerçekleştirilmiştir. Bu çalışmanın sonucunda, ZDFTM sisteminin uygulanması sayesinde genel üretim maliyetlerinin mamullere daha doğru bir şekilde dağıtıldı̆̆ ve maliyetlerin daha doğru hesaplandı̆̆ görülmektedir. Ayrıca uygulamada, normal zaman kayıplarına ilave olarak, atıl kapasite tespit edilmiştir. Üretimde meydana gelen gereksiz zaman kayıplarının sonucu oluşan atıl kapasitenin, firma tarafindan elimine edilmesi gerekmektedir. Yeni bir çağdaş maliyetleme yöntemi olan ZDFTM ile ilgili yapılmış çalıșmaların az olması ve ilaç üretimi alanında çalışmanın olmaması sebebiyle çalışmanın alana önemli katkl sağlayacağı düşünülmektedir.
\end{abstract}

Anahtar Kelimeler: Zamana Dayalı Faaliyet Tabanlı Maliyetleme Sistemi, Çağdaş Maliyetleme Sistemleri, Atıl Kapasite.

JEL Sinıflandirmast: D24, $M 41$

\section{Time Driven Activity Based Costing And An Application}

\section{ABSTRACT}

In this study, as one of the contemporary costing systems, Time Driven Activity-Based Costing system (TDABC) is applied to a firm that produces drugs. The firm distributes the general production costs according to the traditional methods and cannot accurately calculate the product costs. Therefore, the aim of this study is to investigate the applicability of the TDABC method which is one of the contemporary costing systems and enables a more accurate calculation of product costs, in the firm. Furthermore, in the study, it is aimed to determine the general production cost share of the products and to compare these results with the results of the company's existing cost calculations. For this purpose, observations were made in the factory and interviews were had with the managers in the factory about the application of the TDABC system. Implementation of the system was performed by means of the obtained data. The study results indicate that through the implication of TDABC system, general production costs are more accurately distributed to the individual products, and costs are calculated more accurately. Additionally, application of the system allowed determination of idle capacity in addition to normal time loss. The idle capacity that results from unnecessary loss of time during production should be eliminated by the company. It is thought that studies on TDABC which is a new contemporary costing method are not enough and this study will make a significant contribution to the field because there is not a study about TDABC in medicine production.

Keywords: Time-Driven Activity-Based Costing, Modern Costing Systems, Idle Capacity.

Jel Classification: D24, M41.

Makale Gönderim Tarihi: 10.04.2018

Makale Kabul Tarihi: 21.05.2018

\footnotetext{
${ }^{*}$ Bu çalışma yazarlar tarafindan hazırlanıp yönetilen "Çağdaş Maliyetleme Sistemleri Kapsamında Zamana Dayalı Faaliyet Tabanlı Maliyetleme Sistemi: Irak’taki Bir Üretim İşletmesinde Uygulama” başlıklı yüksek lisans tezinden yararlanılarak hazırlanmıştır.

${ }^{* *}$ Dr. Öğr. Üyesi, Süleyman Demirel Üniversitesi, İktisadi ve İdari Bilimler Fakültesi, samiozturk@ sdu.edu.tr, ORCID ID: 0000-0002-7657-3150

${ }^{* * *}$ saif.alsalman@gmail.com, ORCID ID: 0000-0003-0941-582X
} 


\section{GíRiş}

İşletmeler, belirledikleri hedeflere ulaşabilmek ve başarılı olabilmek için maliyetlerini doğru bir şekilde hesaplayıp analiz etmelerinde, performanslarını geliştirmelerinde ve stratejik karar alma süreçlerinde çağdaş maliyetleme sistemlerinden yararlanmaktadırlar. Çağdaş maliyetleme sistemleri, maliyetleri düşürmek, en yüksek kalite standartları doğrultusunda üretim gerçekleştirmek, müşterilerin beklentilerini doğru ve eksiksiz bir biçimde tam zamanında karşılamak gibi hedefleri gerçekleştirmektedir. Değişen üretim koşulları ile birlikte, üretimde meydana gelen endirekt maliyetlerin artmas1 sonucu, bu maliyetlerin mamullere doğru bir şekilde dağıtımının yapılması hayati önem arz etmektedir. Geleneksel maliyetleme sisteminde genel üretim giderlerinin mamullere dağitılmasında pek çok sorun meydana gelmektedir. Bundan dolayı üretim maliyetleri doğru hesaplanamamaktadır. Endirekt maliyetlerin daha doğru bir biçimde dağıtılması için çağdaş maliyetleme sistemlerinden faydalanılmaktadır. Bu sistemlerden birisi de Zamana Dayalı Faaliyet Tabanlı Maliyetleme (ZDFTM) sistemidir.

$\mathrm{Bu}$ çalş̧mada ilaç üretimi yapan bir işletmede ZDFTM sisteminin uygulaması gerçekleştirilmektedir. Firmadan elde edilen bilgilere göre, araştırmanın gerçekleştirildiği zaman diliminde, işletmede şurup ve tablet olmak üzere iki farklı mamul üretilmektedir. Firma, ürettiği iki farklı mamul grubuna ait üretim hattına, eşit bir şekilde genel üretim maliyetlerini dağıtmaktadır. Firmanın geleneksel yöntemlerle dağıtım yapması ve mamullerin maliyetinin doğru bir şekilde hesaplanmaması sebebiyle çalışmada ZDFTM sisteminin uygulanması amaçlanmaktadır.

\section{ZAMANA DAYALI FAALIYET TABANLI MALIYETLE SISTEMI}

ZDFTM, geleneksel Faaliyet Tabanlı Maliyetleme (FTM) sistemini temel alan bir yöntemdir. Ancak, düşük uygulama maliyetleri, zaman yönetimindeki verimliliği ve uygulama, adaptasyon ve modernizasyon kolaylı̆g sayesinde, kaynak akışına yönelik gerçek kapasiteye dayalı maliyet etkinliğini ve buna dayalı oranları belirlemeye yardımcı olmaktadır (Szychta, 2010: 53). Geleneksel FTM'nin geliştirilmiş bir şekli olarak düşünülen ZDFTM, işletme faaliyetlerinin gerçekleştirilmesi için gerekli süre ile kapasite birim süre maliyeti yardımıyla işlemlerin, mamullerin veya kaynak taleplerinin tahmin edilmesine yardımcı olan bir sistemdir (Koşan, 2007: 160). Ürün ve hizmetlerde herhangi bir değişiklik meydana gelmesi durumunda, ZDFTM sistemi, bu değişikliklere adaptasyonu kolayca sağlayan zamana dayalı denklemlerin kullanılması nedeniyle karmaşı faaliyetler içeren ticari işletmelerde oldukça uygun olan bir sistemdir. İşletme ZDFTM ile, var olan tüm maliyet sistemini gözden geçirmek yerine gerekli değişikliklerin sisteme kolayca dahil edilmesiyle daha kolay ve hızlı bir çözüm elde etmektedir (Oliveira ve Oliveira, 2015:3).

ZDFTM sisteminin özellikleri şu şekilde suralanabilmektedir (Kaplan ve Anderson, 2003: 1):

1. Öngörülebilir, tahmin edilebilir ve hızlı bir şekilde kurulabilir.

2. Süreçlerdeki değişikliği, sipariş çeşitliliğini ve kaynak maliyetlerini yansıtacak şekilde kolayca güncellenir. 
3. Kurumsal Kaynak Planlaması ve Müşteri İlişkileri Yönetimi sistemlerinden alınan verilerle beslenir.

4. Sistem, sürece dair tahmini süreyi doğrudan gözlemleyerek modül formunda bunu doğrulayabilir.

5. ZDFTM sistemi ile oldukça çok sayıda işlem, tam zamanında kolaylıkla ölçülebilir, hesaplanabilir, teslim edilebilir ve raporlanabilir.

6. Sistem, işletme yönetiminin doğru kararlar vermesine yardımcı olmak için atıl kapasiteye dikkat çekmektedir.

7. Sistem, var olan modeli genişletmeden ya da değiştirmeden, müşteri siparişlerinin çeşitliliğgini karşılamak için zaman denklemlerini kullanır.

ZDFTM sayesinde, yöneticilere daha anlamlı maliyet ve karlılık verileri daha hızlı ve az maliyetle sunulabilmektedir. Bu sistem ile her işlem, ürün ve müşterinin ihtiyaç duyduğu kaynak talebi, önce faaliyetler bazında daha sonra da ürünler ve müssteriler bazında belirlenmektedir (Yükçü ve Gönen, 2009: 21). ZDFTM endirekt maliyetleri, her faaliyet için kullanılan aktif işgücü süresine bağlı olarak dağıtmaktadır. Üretilen mal veya hizmetlerin, farklı süreçlerden geçmesi ve farklı sürede gerçekleştirilmeleri sebebiyle, kaynakları da farklı miktarda tükettiği düşünülmektedir. Bu sebeple çalışanların çalışma süreleri dikkate alınarak ilgili maliyetler, ürün veya hizmetlere dağıtılmaktadır (Köse, 2010:161).

ZDFTM sisteminin uygulama aşamalarını aşağıdaki gibi sıralamak mümkündür (Everaert vd, 2008:175):

1. Farklı kaynak gruplarının belirlenmesi

2. Her kaynak grubunun toplam maliyetinin tahmin edilmesi

3. Her bir kaynak grubunun pratik kapasitesinin tahmin edilmesi

4. Kaynak grubunun toplam maliyetini pratik kapasiteye bölerek her kaynak grubu için birim maliyetin hesaplanması

5. Maliyet objesinin özelliğine ve faaliyetin zaman denklemine göre her maliyet objesi için zaman tahminin belirlenmesi

6. Söz konusu maliyet objesi için zaman tahmini ile her kaynak grubunun birim maliyetinin çarpılması

ZDFTM, sürecin işlerliğini sağlamak için iki parametreye ihtiyaç duymaktadır. Bunlar; tedarik edilen kaynağın (kapasitenin-zamanın) birim maliyeti ile maliyet objeleri için yerine getirilen faaliyetlerce tüketilen kapasite birim zaman yani kaynaklardır (Kaplan ve Anderson, 2004:133).

Kaynakların kapasite birim maliyetini belirlemek amaciyla, ilk olarak kapasite kaynaklarının belirlenmesi gerekir. İşçilerin iş yerinde zamanlarını nasıl harcadıklarını öğrenmek için işçileri takip etmek yerine yöneticiler ile görüşülebilmekte ve yüzde olarak 
kapasite oranı tahmin edilebilmektedir. Genel bir kural olarak pratik kapasite, teorik kapasitenin 80\% ile \% 85'i arasında bir değere eşittir. Makineler haftada 40 saat çalışır durumda olursa, pratik kapasite haftada 32 ile 35 saat arasında olacaktır. Dışlanan \%20 kapasite ise gidiş, dönüş ve iletişim sürelerini, bakım dönemlerini vb. temsil etmektedir (Kaplan ve Anderson, 2004:133).

Birim maliyetler ise şu şekilde hesaplanmaktadır (Kaplan ve Anderson, 2003:7):

Birim maliyet $=$ Tedarik Edilen Kapasite (Kaynak) Maliyeti $/$ Tedarik Edilen Kaynakların Pratik Kapasitesi

Zaman denklemleri, maliyeti oluşturan unsurlar tarafindan kullanılan zamanı belirlemek için ZDFTM sisteminde kullanılan en önemli araçtır. Bu bağlamda, zaman denklemleri, özellikle operasyonların benzer olduğu tesislerde bir faaliyet yürütmek için gereken süreyi belirlemek adına önemli ve kullanışlı bir araçtır (Polat, 2011: 129). Demireli ve Yılmaz'a göre ise, zaman denklemlerinin ZDFTM sisteminin en önemli özelliklerinden biri olduğu ve zaman denklemlerinin kullanılmasıyla karmaşık süreçlerin kolayca tanımlanabilir hale geldiği düşünülmektedir. Ayrıca, çalışma koşulları değişse bile, bu denklemler değişen koşullara göre kolayca güncellenebilmektedir (Demireli ve Yılmaz, 2013: 302). Zaman denklemleri, her bir işlem için gerekli olan faaliyetlerin gerçekleştirilmesinde ihtiyaç duyulan zamanı belirlemek için kullanılır. Her bir faaliyet için gereken zaman belirlenerek, birim maliyet tutarı, tahmini etkinlik süresi ile çarpılır. Bu işlemde zaman birimi dakika olarak alınmaktadır. Zaman eşdeğerleri ve birim miktarlara dair bilgiler, tesisteki mevcut bilgi sistemlerinden akışı sağlanan verilerden elde edilebilir (Hoozee ve Bruggeman, 2010:186). Zaman denklemlerine ait simgeler şu şekilde açıklanabilmektedir (Dejnega, 2011:9; Cengiz, 2011: 41):

1. A faaliyet'te bulunan $\mathrm{E}$ olayın maliyeti $=\mathrm{T}_{\mathrm{E}, \mathrm{A}} * \mathrm{Ci}$

$\mathrm{T}_{\mathrm{E}, \mathrm{A}}=\mathrm{A}$ faaliyet'teki E olay gerçekleştirilmesi için harcanan zaman.

$\mathrm{Ci}=$ kaynakların zaman birimi başına maliyeti

2. A faaliyet'teki E olayın gerçekleştirilmesi için harcanan zamana ulaşılması için şu denklem kullanılmaktadır:

$\mathrm{T}_{\mathrm{E}, \mathrm{A}}=\mathrm{B}_{0}+\mathrm{B}_{1} * \mathrm{X}_{1}+\mathrm{B}_{2} * \mathrm{X}_{2}+\mathrm{B}_{3} * \mathrm{X}_{3}+\ldots \ldots \mathrm{B}_{\mathrm{P}} * \mathrm{X}_{\mathrm{P}}$

$\mathrm{B}_{0}=\mathrm{E}$ olayının sabit süresini temsil eder.

$\mathrm{B}_{1}=\mathrm{Bir}$ birim için (X1) zaman etkeni tarafından harcanan zaman

$\mathrm{X}_{1}=$ zaman etkeni 1

$\mathrm{X}_{2}=$ zaman etkeni 2 . 


\section{UYGULAMA}

Bu çalışmada, bir ilaç üretim firmasında Zamana Dayalı Faaliyet Tabanlı Maliyetleme sisteminin uygulaması gerçekleștirilmektedir. Çalışmanın amacı geleneksel yöntemlere göre genel üretim giderlerini mamullere dağıtan bir firmada, ZDFTM sisteminin uygulanması ve ulaşılan sonuçlar ile firmanın uyguladığı geleneksel maliyet dağıtım yöntemi sonuçları arasındaki farklılıkların incelenmesidir. Çalışmaya konu olan ilaç firması, üretim maliyetlerini hesaplarken genel üretim giderlerini kendi yöntemleriyle mamullere dağıtmaktadır. Ancak bu dağıtım bilimsel, teknik ve çağdaş yöntemlere göre yapılmadığından, firmanın, daha etkin ve çağdaş yöntemlerle, genel üretim giderlerini mamullere yüklemesi gerekmektedir. Bu temel problemden yola çıkılarak, firmada çağdaş maliyetleme sistemlerinden birisi olan ZDFTM sistemine yönelik bir örnek uygulama yapılmıştır. ZDFTM sisteminin firmada uygulanabilmesi için, firmanın üretim hattında gözlemlemeler yapılarak ve firma yöneticileri ile yapılan görüşmeler neticesinde bilgi elde edilmiş̧tir. Firmadaki üretim hattı gözlemlenerek mamullerin üretim aşamaları tespit edilmiş, çalışanların ve makinelerin ilgili kısımlardaki çalışma süreleri hesaplanmıștır. Firma yöneticileri ile yapılan görüşmeler sonucunda ise üretimin pratik kapasitesi belirlenmiştir. Elde edilen bilgiler ile zamana dayalı faaliyet tabanlı maliyetleme sistemi firmada uygulanmıştr.

Firmanın üretim yaptığı fabrika 1998 yılında özel sektörde faaliyet göstermek üzere kurulmuştur. Fabrikada şurup ve tablet olmak üzere iki üretim hattı bulunmaktadır. Fabrika alanı yaklaşık 2500 metrekaredir. Firmada yönetim personeli ve üretim hatlarında çalışan işçiler dahil olmak üzere toplam 44 çalışan istihdam edilmektedir. Firmadaki üretim süreci, fabrikada üretilen ürünlerin müşteriler tarafindan talep edilmesi ile birlikte, açılan talebin pazarlama departmanı tarafindan yönetime iletilmesi ile başlamaktadır. Yönetimin onayının ardından, talebin onay süreci tamamlanmış olur. Talep edilen ürüne ilişkin olarak gerekli üretim miktarı belirlenmekte ve üretim müdürü tarafindan bir üretim planı hazırlanmaktadır. Stok yönetimini kontrol eden depo birimi, üretim faaliyetleri için ihtiyaç duyulan hammaddeleri hazırlamakta ve bunları üretim bölümüne göndermektedir. Depodan üretim kısmına hammaddelerin gönderilmesinin ardından, üretim departmanı müşteri tarafindan talep edilen ürünün türüne göre, gerekli hammaddeleri üretim bandına göndermekte ve gönderilen hammadde, çeşitli aşamalardan geçirilerek üretim süreci tamamlanmaktadır.

\subsection{Firma Tarafindan Uygulanan Maliyet Hesaplamaları}

Mevcut durum itibariyle firma, ürettiği ürünlerin maliyetini geleneksel yöntemlerle hesaplamaktadır. İşletmedeki bütün işçilik giderleri endirekt olup, genel üretim giderleri altında yer almaktadır. İşçiler iki üretim hattında birden çalıştıkları için iş̧ilik giderleri mamuller bazında ayrılamamaktadır. Direkt iş̧̧ilik giderinin bulunmaması sebebiyle, firma direkt ilk madde ve malzeme giderleri ile genel üretim giderlerinin toplanması suretiyle mamul maliyetlerini hesaplamaktadır. Şurup ve tabletin hammaddeleri ile ambalaj ve paketleme malzemeleri ayrı olduğu için, direkt ilk madde ve malzeme giderleri içinde hammadde maliyetleri ile ambalaj ve paketleme malzeme giderleri yer almaktadır. Direkt ilk madde ve malzeme giderlerinin dışında kalan giderler ile endirekt işçilik giderleri ve diğer endirekt giderler toplanarak genel üretim giderleri hesaplanmaktadır.

Mamullerin birim maliyetlerinin hesaplanabilmesi için öncelikle direkt ilk madde ve malzeme giderleri her bir mamul grubu için belirlenmektedir. Daha sonra toplam olarak 
hesaplanan genel üretim giderleri mamul grubuna dağıtılarak, mamul gruplarının ayrı ayrı toplam maliyetleri belirlenmektedir. Mamul gruplarının toplam maliyetleri üretilen mamul sayısına bölünerek birim mamul maliyetleri hesaplanmaktadır. Firma tarafindan uygulanan maliyet yöntemine göre, toplam genel üretim giderlerinin yarısı şurubun maliyetine, diğer yarısı ise tabletin maliyetine dağıtılmaktadır. Aralık 2016 yılı verilerine göre firma şurup ve tablet olmak üzere iki çeşit mamul üretmektedir. Öncelikle bir şişe şurubun maliyeti aşağıdaki gibi hesaplanmaktadır:

Şurubun Direkt İlk Madde ve Malzeme Maliyeti = Şurubun hammadde maliyeti + Ambalajlama malzeme maliyeti

Şurubun direkt ilk madde ve malzeme maliyeti hesaplanırken, öncelikle her 1000 litre ilaç için hammadde ve ambalaj malzeme maliyetleri belirlenmektedir. Çünkü her bir malzeme grubundan 1000 litre şurup üretimi yapılmaktadır. Her şişe $100 \mathrm{ml}$ yani 0,1 litre ilaç içerdiği için;

1.000 litre / 0,1 litre $=10.000$ adet şişe için direkt ilk madde ve malzeme gideri hesaplanmaktadır. Yani her 10.000 şişe için direkt ilk madde ve malzeme maliyeti belirlenmektedir. Daha sonra toplam direkt ilk madde ve malzeme maliyeti 10.000'e bölünerek bir şişe şurup başına düşen ilk madde ve malzeme gideri hesaplanmaktadır. Firmanın yaptığı hesaplamalara göre her 10.000 şişe şurup için hammadde maliyeti 1.010 \$ ve ambalaj malzemesi maliyeti ise 1.953 \$ olarak tespit edilmiştir.

Şurubun direkt ilk madde ve malzeme maliyeti $=1.010 \$+1.953 \$=2.963 \$$ 'dır. Bir şişe şurubun direkt ilk madde ve malzeme maliyetinin (DIMM) hesaplanması için direkt ilk madde ve malzeme maliyeti 10.000 şişeye bölünmektedir.

Bir şişe şurubun DIMM $=2.963 \$ / 10.000$ şişe $=0,30$ \$'dır. Aralık 2016 dönemi boyunca toplam 63.000 litre şurup üretilmiştir. Bir şişede $100 \mathrm{ml}$ yani 0,1 litre ilaç bulunduğu için toplam $630.000(63.000 / 0,1)$ şişe şurup üretimi gerçekleştirilmiştir. Bir ay içinde üretilen şurubun toplam direkt ilk madde ve malzeme maliyeti aşa ğıdaki gibi hesaplanmaktadır:

Şurup üretiminin toplam DİMM = 1 şişe şurubun DİMM x 630.000 şişe

$=0,2963 \$ \times 630.000$ şişe $=186.669 \$$ 'dır. Firma tarafindan bütün endirekt giderler toplanarak toplam genel üretim gideri hesaplanmaktadır. Aralık ayı boyunca gerçekleşen bütün endirekt giderler ve tutarları aşağıdaki tabloda belirtilmektedir:

Tablo 1. Aralık Ayı Genel Üretim Giderleri

\begin{tabular}{|l|c|}
\hline Genel Üretim Giderleri & Tutar $\mathbf{( \$ )}$ \\
\hline Ücret ve Maaşlar & 23.350 \\
\hline Yakıt Gideri & 2.944 \\
\hline Bakım Gideri & 4.913 \\
\hline Taşıma Gideri & 2.000 \\
\hline Amortisman Gideri & 13.900 \\
\hline İlaç Analiz Gideri & 812 \\
\hline Endirekt Malzeme Gideri & 956 \\
\hline Diğgr Üretim Giderleri & 2.673 \\
\hline TOPLAM & $\mathbf{5 1 . 5 4 8}$ \\
\hline
\end{tabular}


Yukarıda belirtilen bütün endirekt giderler, hem şurup üretiminde hem de tablet üretiminde ortak olarak kullanılmaktadır. $\mathrm{Bu}$ giderler, şurup ve tablete doğrudan yüklenemediği için genel üretim giderleri altında sınıflandırılmaktadır. Tabloda görüldüğü üzere Aralık ayında gerçekleşen genel üretim gideri toplamının 51.548 \$ olduğu tespit edilmiştir. Daha sonra toplam genel üretim gideri firma tarafından ikiye bölünerek şurup ve tablete dağıtılmaktadır. Şurup ve tablet mamul grubunun her birine düşen genel üretim gideri;

\section{$51.548 \$ / 2=25.774 \$$ 'dir.}

Bir şişe şuruba düşen genel üretim gideri ise aşağıdaki gibi hesaplanmaktadır:

Bir şişe şurubun genel üretim gideri = Şurup mamul grubunun toplam genel üretim gideri / Aralık ayı şurup üretim miktarı.

$=25.774 \$ / 630.000$ şişe $=0,04$ \$'dır.

Birim başına düşen direkt ilk madde ve malzeme maliyeti ile genel üretim gideri toplanarak bir şişe şurubun toplam maliyeti aşağıdaki gibi hesaplanmaktadır.

Tablo 2. Bir Şişe Şurubun Toplam Maliyeti

\begin{tabular}{|c|c|c|c|}
\hline Açılama & Toplam Maliyet (\$) & Üretilen Mamul Sayısı & Birim Maliyet (\$) \\
\hline $\begin{array}{c}\text { Direkt İlk Madde ve } \\
\text { Malzeme Gideri }\end{array}$ & 186.669 & 630.000 & 0,30 \\
\hline Genel Üretim Gideri & 25.774 & 630.000 & 0,04 \\
\hline TOPLAM & $\mathbf{2 1 2 . 4 4 3}$ & $\mathbf{6 3 0 . 0 0 0}$ & $\mathbf{0 , 3 4}$ \\
\hline
\end{tabular}

Yukarıdaki tabloda görüldüğü üzere firmanın hesaplamalarına göre bir şişe şurubun maliyeti yaklaşık 0,34 \$'dır. Fabrikada üretilen diğer bir mamul ise tablettir. Şurup kısmında olduğu gibi aynı yöntem kullanılarak, tabletin maliyeti hesaplanmaktadır. Tabletin direkt ilk madde ve malzeme maliyeti hesaplanırken, her 500.000 tablet ilaç için hammadde ve ambalaj malzeme maliyetleri belirlenmektedir. Çünkü her bir malzeme grubundan 500.000 adet tablet üretimi yapılmaktadır. Her blisterde ${ }^{1} 10$ adet tablet yer aldığ 1 için;

500.000 tablet $/ 10$ tablet $=50.000$ adet blister için direkt ilk madde ve malzeme gideri hesaplanmaktadır. Yani her 50.000 adet blister için direkt ilk madde ve malzeme maliyeti belirlenmektedir. Daha sonra, direkt ilk madde ve malzeme maliyeti 50.000'e bölünerek bir adet blister başına düşen ilk madde ve malzeme gideri hesaplanmaktadır. Firmanın yaptığ 1 hesaplamalara göre her 50.000 adet blister için Aralık 2016 döneminde direkt ilk madde ve malzeme maliyeti 1.478 \$ olarak tespit edilmiştir.

Bir adet blisterin DİMM $=1.478 \$$ / 50.000 blister $=0,03 \$$ 'dır.

Aralık 2016 dönemi boyunca toplam 2.040.000 adet blister üretilmiştir. Dolayısıyla bir ay içinde üretilen blisterin toplam DİMM aşağıdaki gibi hesaplanmaktadır:

Blisterin toplam DİMM = 1 adet blisterin DİMM x 2.040.000 adet blister

\footnotetext{
${ }^{1}$ Blister: Tablet halindeki ilaçların ticari sunumları kapsamında kullanılan ambalaj türüdür.
} 


$$
=0,03 \$ \times 2.040 .000 \text { blister }=60.302 \$ \text { 'dir. }
$$

Tablete düşen genel üretim gideri payı toplam genel üretim giderinin yarısı olup 25.774 \$'dır. Toplam 2.040.000 adet blister üretildiği için, bir adet blistere düşen genel üretim gideri ise aşağıdaki gibi hesaplanmaktadır:

$$
=25.774 \$ / 2.040 .000 \text { adet blister }=0,01 \$ \text { 'dir. }
$$

Birim başına düşen direkt ilk madde ve malzeme maliyeti ile genel üretim gideri toplanarak, bir adet blisterin toplam maliyeti aşağıdaki gibi hesaplanmaktadır.

Tablo 3. Bir Adet Blisterin Toplam Maliyeti

\begin{tabular}{|c|c|c|c|}
\hline Açıklama & Toplam Maliyet (\$) & $\begin{array}{c}\text { Üretilen Mamul } \\
\text { Sayısı }\end{array}$ & Birim Maliyet (\$) \\
\hline $\begin{array}{c}\text { Direkt İlk Madde ve } \\
\text { Malzeme Gideri }\end{array}$ & 60.302 & 2.040 .000 & 0,03 \\
\hline Genel Üretim Gideri & 25.774 & 2.040 .000 & 0,01 \\
\hline Toplam & $\mathbf{8 6 . 0 7 6}$ & $\mathbf{2 . 0 4 0 . 0 0 0}$ & $\mathbf{0 , 0 4}$ \\
\hline
\end{tabular}

\subsection{Zamana Dayalı Faaliyet Tabanlı Maliyetleme Uygulaması}

Yapılan uygulamada öncelikle üretilen şuruplar için ZDFTM uygulaması gerçekleştirilmektedir. Uygulamada takip edilecek işlemler aşağıda adımlar halinde gösterilmektedir.

Adım 1-2: Birinci adım genel üretim giderlerini ifade eden kaynak gruplarının belirlenmesidir. İkinci adım ise bu kaynak gruplarının toplam maliyetlerinin tespit edilmesidir. Firmadan alınan maliyet verilerine göre kaynak grupları ve tutarları aşağıdaki tabloda gösterilmektedir:

Tablo 4. Kaynak Grupları ve Tutarları

\begin{tabular}{|c|c|}
\hline Açıklama & Tutar (\$) \\
\hline Ücret ve Maaşlar & 23.350 \\
\hline Yakit Gideri & 2.944 \\
\hline Bakım Gideri & 4.913 \\
\hline Taşıma Gideri & 2.000 \\
\hline Amortisman Gideri & 13.900 \\
\hline İlaç Analiz Gideri & 812 \\
\hline $\begin{array}{c}\text { Endirekt Malzeme (İşçilerin üretim gereksinimlerine ait } \\
\text { malzeme giderleri) }\end{array}$ & 956 \\
\hline Diğer Üretim Giderleri & 2.673 \\
\hline TOPLAM & $\mathbf{5 1 . 5 4 8}$ \\
\hline
\end{tabular}

Adım 3: Üçüncü adım üretimin pratik kapasitesinin belirlenmesidir. Pratik kapasite hesaplanırken fabrika müdürü ile gerçekleştirilen görüşme neticesinde elde edilen bilgilerden yararlanılmıştır. Alınan bilgilere göre, personel için resmi çalışma saatleri, sabah saat 8:00'da başlayıp saat 14:00'da sona ermektedir. Dolayısıyla günlük çalışma saati 6 saattir. Haftalık 
çalışma günü sayısı ise 6 gündür. Ayrıca çalışma yapılan 2016 yılının Aralık ayında 26 işgünü bulunmaktadır. Fabrikada toplam 44 kişi çalışmaktadır. Bu verilerin ışığında öncelikle dakika cinsinden aylık teorik kapasitenin tespit edilmesi gerekmektedir:

Aylık İşgücü Teorik Kapasitesi $=(6$ saat x 26 iş günü $\mathrm{x} 44$ işçi $)$ x 60 dakika = 411.840 dakikadır. Teorik kapasitenin tespit edilmesinin ardından işgücünün pratik kapasitesi belirlenmektedir. Fabrika müdürü ile yapılan görüşmelerden elde edilen verilere göre pratik kapasite, hem işgücü hem de makineler için teorik kapasitenin \%80'idir. Firmanın işgücü pratik kapasitesi aşağıdaki gibi hesaplanmaktadır:

İşücü Pratik Kapasitesi $=411.840 \mathrm{dk} / \mathrm{ay} \mathrm{x} \% 80=329.472$ dakika/ay.

Fabrikada üretimde kullanılan 7 adet makine bulunmaktadır. Makinelerin pratik kapasitesi ise aşağıdaki gibi hesaplanmaktadır:

Makinelerin Aylık Teorik Kapasitesi $=(6$ saat $\times 26$ iş günü $\mathrm{x} 7$ makine $) \times 60$ dakika $=$ 65.520 dakikadır.

Makinelerin Aylık Pratik Kapasitesi $=65.520$ dk/ay x $\% 80=52.416$ dakikadır.

Adım4: Kaynak gruplarının toplam maliyeti pratik kapasiteye bölünerek her kaynak grubu için birim maliyet hesaplanmaktadır. Kaynak gruplarının birim maliyetlerinin belirlenmesi için iki zaman etkeni seçilmiştir. Bunlar işgücü çalışma süresi ve makine çalışma süresidir. Kaynak gruplarının hangilerinin işgücüne hangilerinin ise makinelere dayandığ tespit edilmiştir. Buna göre; ücret ve maaşlar, taşıma giderleri, ilaç analiz giderleri, endirekt malzeme gideri, diğer üretim giderleri işgücü çalışmasına dayandığı için bunların zaman etkeni işgücü çalışma süreleridir. Yakıt gideri, bakım gideri ve amortisman gideri makinelerin çalışmasına dayandığı için zamana etkeni makine çalışma süreleridir. Kaynak gruplarının dakika başına birim maliyetleri, her bir genel üretim gideri tutarının pratik kapasiteye bölünmesiyle aşağıdaki gibi hesaplanmaktadır:

Tablo 5. Kaynak Gruplarının Dakika Başına Maliyetleri

\begin{tabular}{|c|c|c|c|c|}
\hline Kaynak & $\begin{array}{c}\text { Tutar } \\
\mathbf{( \$ )}\end{array}$ & Zaman Etkeni & $\begin{array}{c}\text { Pratik } \\
\text { Kapasite } \\
\text { (dakika/ay) }\end{array}$ & $\begin{array}{c}\text { Dakika Başına } \\
\text { Maliyet (\$/dk) }\end{array}$ \\
\hline Ücret ve Maaşlar & 23.350 & $\begin{array}{c}\text { İşgücü Çalışma } \\
\text { Süresi }\end{array}$ & 329.472 & 0,07 \\
\hline Yakıt Gideri & 2.944 & $\begin{array}{c}\text { Makine Çalışma } \\
\text { Süresi }\end{array}$ & 52.416 & 0,06 \\
\hline Bakım Gideri & 4.913 & $\begin{array}{c}\text { Makine Çalı̧ma } \\
\text { Süresi }\end{array}$ & 52.416 & 0,09 \\
\hline Taşıma Gideri & 2.000 & $\begin{array}{c}\text { Isşgücü Çalışma } \\
\text { Süresi }\end{array}$ & 329.472 & 0,01 \\
\hline Amortisman Gideri & 13.900 & $\begin{array}{c}\text { Makine Çalı̧̧̧ma } \\
\text { Süresi }\end{array}$ & 52.416 & 0,27 \\
\hline İlaç Analiz Gideri & 812 & $\begin{array}{c}\text { Isşgücü Çalışma } \\
\text { Süresi }\end{array}$ & 329.472 & 0,002 \\
\hline $\begin{array}{c}\text { Endirekt Malzeme Gideri (İşçiler ile } \\
\text { ilgili) }\end{array}$ & 956 & $\begin{array}{c}\text { İşgücü Çalışma } \\
\text { Süresi }\end{array}$ & 329.472 & 0,003 \\
\hline $\begin{array}{c}\text { Diğer Üretim Giderleri (İşçiler ile } \\
\text { ilgili) }\end{array}$ & 2.673 & $\begin{array}{c}\text { Isşgücü Çalışma } \\
\text { Süresi }\end{array}$ & 329.472 & 0,01 \\
\hline
\end{tabular}


Adım 5: Beşinci adım, üretim sürecindeki faaliyetlerin gerçekleşme zamanlarının belirlenmesidir. Faaliyetlerin gerçekleşme zamanları fabrikada üretim sürecinde yapılan gözlemlemeler sonucunda hesaplanmıştır. Şurup ve tabletin üretim faaliyetlerinin zamanları ayrı ayrı tespit edilmiştir. Şurup üretimi ile ilgili faaliyetlerin dakika cinsinden gerçekleşme zamanları aşağıdaki gibi hesaplanmaktadır:

Tablo 6. Şurup Üretimi İle İlgili Faaliyetlerin Gerçekleşme Zamanları

\begin{tabular}{|c|c|c|c|c|}
\hline \multirow{2}{*}{ Faaliyetler } & \multirow{2}{*}{$\begin{array}{c}\text { Ölçü } \\
\text { Birimi }\end{array}$} & \multicolumn{2}{c|}{$\begin{array}{c}\text { Faaliyetin Uygulanması } \\
\text { İçin Gerekli Kaynaklar }\end{array}$} & \multirow{2}{*}{$\begin{array}{c}\text { Süre } \\
\text { (Dakika) }\end{array}$} \\
\cline { 3 - 4 } & & Makine & İçilik & \\
\hline Makine ve Ekipmanın Sterilizasyonu & 1000 litre & & $\mathbf{x}$ & $\mathbf{6 8}$ \\
\hline $\begin{array}{c}\text { Hammaddelerin Ayrılması ve } \\
\text { Sınıflandırılması }\end{array}$ & 1000 litre & & $\mathbf{8 5}$ & \\
\hline $\begin{array}{c}\text { Hammaddelerin Hazırlık Odasına } \\
\text { Gönderilmesi }\end{array}$ & 1000 litre & & $\mathbf{x}$ & $\mathbf{2 7}$ \\
\hline $\begin{array}{c}\text { Hammaddelerin Hazırlama Tankına } \\
\text { Boşaltılması }\end{array}$ & 1000 litre & & $\mathbf{x}$ & $\mathbf{2 1}$ \\
\hline $\begin{array}{c}\text { Preparatın (ilacın) Üretilmesi } \\
\text { Preparatın İncelenmesi }\end{array}$ & 1000 litre & $\mathbf{x}$ & $\mathbf{7 5}$ \\
\hline $\begin{array}{c}\text { Preparatın Paketleme Makinesinin } \\
\text { Bulunduğu Kısma Taşınması }\end{array}$ & 1000 litre & & $\mathbf{x}$ & $\mathbf{5 1}$ \\
\hline Ambalajlama Süreci & 1000 litre & $\mathbf{x}$ & $\mathbf{3 0}$ \\
\hline $\begin{array}{c}\text { Ürünlerin İşçiler Tarafından Paket } \\
\text { İçerisinde Paketlenmesi }\end{array}$ & 1 paket & & $\mathbf{x}$ & $\mathbf{2 6 0}$ \\
\hline $\begin{array}{c}\text { Ürünlerin, Mamul Depolarına } \\
\text { Taşınmasıdır }\end{array}$ & 150 paket & & $\mathbf{1 0}$ & $\mathbf{1 7}$ \\
\hline
\end{tabular}

Yukarıda belirtilen hesaplamalara ait açıklamalar aşağıda yer almaktadır:

Şurup üretiminde gerçekleştirilen faaliyetlerin zamanları hesaplanırken her 1.000 litre ilaç üretimi için gerekli süreler dikkate alınmıştır. Çünkü şurup üretimi 1.000 'er litrelik üretimler halinde gerçekleştirilmektedir. Yani bir sefer şurup üretiminde 1.000 litre ilaç üretilmektedir. Makine ve ekipmanın sterilizasyonu süresi her 1.000 litre ilaç için 68 dakika iş gücü çalışma süresidir. Hammaddelerin ayrılması ve sınıflandırılması süresi her 1.000 litre ilaç için 85 dakika iş gücü çalışma süresidir. Hammaddelerin hazırlık odasına gönderilmesi süresi her 1.000 litre ilaç için 27 dakika iş gücü çalışma süresidir. Hammaddelerin hazırlama tankına boşaltılması süresi her 1.000 litre ilaç için 21 dakika iş gücü çalışma süresidir. Preparatın üretim süresi her 1.000 litre ilaç için 75 dakika makine çalışma süresidir. Preparatın incelenmesi süresi her 1.000 litre ilaç için 51 dakika iş gücü çalışma süresidir. Preparatın paketleme makinesine taşınma süresi her 1.000 litre ilaç için 30 dakika iş gücü çalışma süresidir. Ambalajlama süresi her 1.000 litre ilaç için 260 dakika makine çalışma süresidir. İşgücü çalışma süresi esas alınarak ürünlerin paketlenmesi ise her paket başına 10 dakika sürmektedir. Ürünler mamul depolarına 150'şer paketler halinde taşındığ 1 için her 150 paketin mamul depolarına taşıma süresi 17 dakika iş gücü çalışma süresidir. $\mathrm{Bu}$ adımın devamında ise üretim faaliyetlerinin toplam sürelerinin hesaplanması için zaman denklemlerinin kurulması gerekmektedir. Uygulamada oluşturulan zaman denklemleri aşağıda yer almaktadır:

Şurup üretim faaliyetlerinin aylık toplam süresi $=B_{1} * X_{1}+B_{2} * X_{1}+B_{3} * X_{1}+B_{4} * X_{1}+$

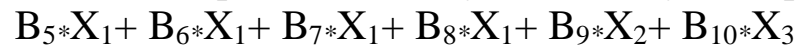


$\mathrm{B}_{1=}$ Her 1.000 litre için makine ve ekipmanın sterilizasyon süresi

$\mathrm{B}_{2=}$ Her 1.000 litre için hammaddelerin ayrılması ve sınıflandırılma süresi

$\mathrm{B}_{3=}$ Her 1.000 litre için hammaddelerin hazırlık odasına gönderilme süresi

$\mathrm{B}_{4=}$ Her 1.000 litre için hammaddelerin hazırlama tankına boşaltılma süresi

$\mathrm{B}_{5=}$ Her 1.000 litre için preparatın üretim süresi

$\mathrm{B}_{6=}$ Her 1.000 litre için preparatın incelenme süresi

$\mathrm{B}_{7=}$ Her 1.000 litre için preparatın paketleme makinesine taşınma süresi

$\mathrm{B}_{8=}$ Her 1.000 litre için ambalajlama süresi

$\mathrm{B}_{9=}$ Her bir paket için ürünlerin paketlenme süresi

$\mathrm{B}_{10=}$ Her 150 paket için ürünlerin mamul depolarına taşıma süresi

$\mathrm{X}_{1=} 1$ ay boyunca 1.000 'er litreler halinde kaç sefer üretim yapıldı̆̆ 1

$\mathrm{X}_{2=} 1$ ay boyunca kullanılan paket sayıs

$\mathrm{X}_{3=} 1$ ay boyunca 150 'şer paketler halinde kaç defa taşıma yapıldı̆̆

Oluşturulan zaman denklemlerinde, şurup ve tablet üretiminde üretim öncesinde sabit

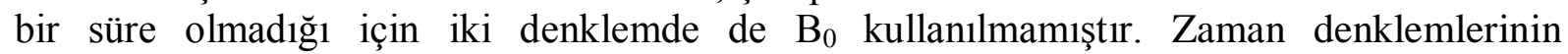
oluşturulmasının ardından şurup üretimi için gerekli faaliyetlerin aylık toplam süreleri, zaman denklemleri kullanılarak aşağıdaki gibi hesaplanmaktadır:

Tablo 7. Şurup Üretimindeki Faaliyetlerin Aylık Toplam Süreleri

\begin{tabular}{|c|c|c|c|c|}
\hline Faaliyet & Zaman & $\begin{array}{c}\text { Aylık } \\
\text { süreç } \\
\text { sayısı } \\
(\mathbf{X})\end{array}$ & $\begin{array}{c}\text { Toplam } \\
\text { Süre (dk) }\end{array}$ & Kaynak \\
$(\mathbf{B} * \mathbf{X})$ & & \\
\hline Makine ve Ekipmanın Sterilizasyonu & 68 & 63 & 4.284 & İşçilik \\
\hline Hammaddelerin Ayrılması ve Sınıflandırılması & 85 & 63 & 5.355 & İşilik \\
\hline $\begin{array}{c}\text { Hammaddelerin Hazırlık Odasına } \\
\text { Gönderilmesi }\end{array}$ & 27 & 63 & 1.701 & İşçilik \\
\hline $\begin{array}{c}\text { Hammaddelerin Hazırlama Tankına } \\
\text { Boşaltılması }\end{array}$ & 21 & 63 & 1.323 & İşçilik \\
\hline $\begin{array}{c}\text { Preparatın (ilacın) üretilmesi } \\
\text { Preparatın İncelenmesi }\end{array}$ & 75 & 63 & 4.725 & Makine \\
\hline $\begin{array}{c}\text { Preparatın Paketleme Makinesinin Bulunduğu } \\
\text { Kısma Taşınması }\end{array}$ & 30 & 63 & 3.213 & İşçilik \\
\hline Ambalajlama Süreci & 260 & 63 & 16.380 & İşilik \\
\hline $\begin{array}{c}\text { Ürünlerin İşçiler Tarafından Paket İçerisinde } \\
\text { Paketlenmesi }\end{array}$ & 10 & 21.000 & 210.000 & İşçilik \\
\hline Ürünlerin, Mamul Depolarına Taşınmasıdır & 17 & 140 & 2.380 & İşçilik \\
\hline
\end{tabular}


2016 yılının Aralık ayında toplam 63.000 litre üretim gerçekleştirilmiştir. Faaliyetler 1.000 'er litrelik üretimler halinde belirlendiği için, faaliyetlerin gerçekleştirilme sayısı; toplam üretim miktarının 1.000'e bölünmesi suretiyle hesaplanmaktadır. 63.000 litre üretim / 1.000 litre $=63$ defa üretim gerçekleştirilmiştir. Faaliyetlerin aylık toplam süreleri hesaplanırken her bir faaliyetin birim süreleri; üretim sefer sayısı olan 63 ile çarpılmıştır. Her pakette 30 adet şişe bulunmaktadır. Dolayısıyla aylık kullanılan paket sayısı; toplam üretilen şişe sayısının 30'a bölünmesi ile hesaplanmaktadır. 630.000 şişe üretim / 30 şişe $=21.000$ paket kullanılmıştır. Aylık toplam paketleme süresi; birim paketleme süresinin 21.000 paket ile çarpılması suretiyle hesaplanmıştır. Ürünler işçiler tarafindan 150 'şer paketler halinde mamul depolarına taşınmaktadır. Ayda toplam 21.000 paket kullanıldığ 1 için toplam taşıma sayısı şu şekilde hesaplanmaktadır: 21.000 paket $/ 150$ 'şer paket $=140$ adet taşıma. Buna göre aylık toplam taşıma süresi; birim taşıma süresi ile 140 sefer taşımanın çarpıılması ile bulunmaktadır.

Adım6: $\mathrm{Bu}$ adımda üretimde kullanılan faaliyetlerin, genel üretim giderlerinden aldıkları pay hesaplanmaktadır. Şurup üretimindeki faaliyetlerin toplam genel üretim giderlerinden aldıkları pay hesaplanırken, faaliyetlerin aylık toplam süreleri ile dakika başına düşen genel üretim gideri tutarı çarpılmaktadır.

Tablo 7'den yararlanılarak şurup üretimindeki faaliyetlerin toplam süreleri işçilik ve makine olmak üzere ikiye ayrılmıştır. İşçilik ve makine çalışma süreleri şu şekilde hesaplanmaktadır:

$$
\text { İşçilik Kaynağ1 Çalışma (İşlem) Süresi = }
$$

$4.284+5.355+1.701+1.323+3.213+1.890+210.000+2.380=230.146$ dakikadır.

Makine Kaynağı Çalışma (İşılem) Süresi $=4.725+16.380=21.105$ dakikadır.

İşçilik ve makine kaynağına ait işlem süreleri hesaplandıktan sonra bu süreler, dakika başına düşen maliyetler ile çarpılarak şurup üretiminde her bir genel üretim giderine düşen toplam maliyet hesaplanmaktadir.

Tablo 8. Şurup Üretiminde Her Bir Genel Üretim Giderine Düşen Payın Hesaplanması

\begin{tabular}{|c|c|c|c|c|}
\hline Genel Üretim Giderleri & Kaynak & $\begin{array}{c}\text { Toplam } \\
\text { İşlem } \\
\text { Süresi } \\
\text { (Dk.) }\end{array}$ & $\begin{array}{c}\text { Dk. } \\
\text { Başına } \\
\text { Düsşen } \\
\text { Maliyet }\end{array}$ & Toplam Maliyet \\
\hline Ücret ve Maaşlar & İşilik & 230.146 & 0,07 & $16.310,67$ \\
\hline Yakıt Gideri & Makine & 21.105 & 0,06 & $1.185,38$ \\
\hline Bakım Gideri & Makine & 21.105 & 0,09 & $1.978,19$ \\
\hline Taşıma Gideri & İşçilik & 230.146 & 0,01 & $1.397,06$ \\
\hline Amortisman Gideri & Makine & 21.105 & 0,27 & $5.596,75$ \\
\hline İlaç Analiz Gideri & İşçilik & 230.146 & 0,002 & 567,21 \\
\hline $\begin{array}{c}\text { Endirekt Malzeme Gideri } \\
\text { (İşçiler ile ilgili) }\end{array}$ & İşilik & 230.146 & 0,003 & 667,79 \\
\hline $\begin{array}{c}\text { Diğer Üretim Giderleri (İşçiler } \\
\text { ile ilgili) }\end{array}$ & İşçilik & 230.146 & 0,01 & $1.867,17$ \\
\hline TOPLAM & & & & $\mathbf{2 9 . 5 7 0 , 2 3}$ \\
\hline
\end{tabular}


Uygulamanın bu kısmında üretilen tabletler için ZDFTM uygulaması gerçekleştirilmektedir. ZDFTM uygulamasında takip edilecek işılemler aşağıda adımlar halinde gösterilmektedir.

Adım 1-2-3-4: Bu dört adım iki mamul grubu için de aynı olduğu için ve yukarıdaki kısımda şurup için hesaplandığı için tabletler için tekrar hesaplama yapılmayacaktır.

Adım 5: Beşinci adım, üretim sürecindeki faaliyetlerin gerçekleşme zamanlarının belirlenmesidir. Faaliyetlerin gerçekleşme zamanları fabrikada üretim sürecinde yapılan gözlemlemeler sonucunda hesaplanmıştır. Tablet üretimi ile ilgili faaliyetlerin dakika cinsinden gerçekleşme zamanları aşağıdaki gibi hesaplanmaktadır:

Tablo 9. Tablet Üretimi İle İlgili Faaliyetlerin Gerçekleşme Zamanları

\begin{tabular}{|c|c|c|c|c|}
\hline \multirow[t]{2}{*}{ Faaliyet } & \multirow[t]{2}{*}{$\begin{array}{l}\text { Ölçü } \\
\text { Birimi }\end{array}$} & \multicolumn{2}{|c|}{$\begin{array}{c}\text { Faaliyetin uygulanması } \\
\text { için gerekli kaynaklar }\end{array}$} & \multirow[t]{2}{*}{ (Dk)Süre } \\
\hline & & Makineler & şçiliki & \\
\hline Makine ve Ekipmanın Sterilizasyonu & $\begin{array}{c}500.000 \\
\text { tablet }\end{array}$ & & $\mathrm{x}$ & 85 \\
\hline $\begin{array}{c}\text { Hammaddelerin Ayrilması ve } \\
\text { Sinıflandırılması }\end{array}$ & $\begin{array}{c}500.000 \\
\text { tablet }\end{array}$ & & $\mathrm{x}$ & 68 \\
\hline $\begin{array}{l}\text { Hammaddelerin Hazırlık Odasına } \\
\text { Gönderilmesi }\end{array}$ & $\begin{array}{c}500.000 \\
\text { tablet }\end{array}$ & & $\mathrm{x}$ & 20 \\
\hline $\begin{array}{c}\text { Hammaddelerin Makine Tarafindan } \\
\text { Karıștırılması ve Kurut }\end{array}$ & $\begin{array}{c}500.000 \\
\text { tablet }\end{array}$ & $\mathbf{x}$ & & 60 \\
\hline Öğütme İşlemi & $\begin{array}{c}500.000 \\
\text { tablet }\end{array}$ & $\mathrm{x}$ & & 78 \\
\hline Preparatın (ilacın) İncelenmesi & $\begin{array}{c}500.000 \\
\text { tablet }\end{array}$ & & $\mathrm{x}$ & 41 \\
\hline $\begin{array}{c}\text { Toz Halindeki Preparatın Presleme } \\
\text { Makinesine İşçiler Tarafından } \\
\text { Aktarılması }\end{array}$ & $\begin{array}{c}500.000 \\
\text { tablet }\end{array}$ & & $\mathrm{x}$ & 20 \\
\hline $\begin{array}{c}\text { Presleme işlemi (toz halindeki } \\
\text { preparatın tablet haline dönüştürülmesi) }\end{array}$ & $\begin{array}{c}500.000 \\
\text { tablet }\end{array}$ & $\mathrm{x}$ & & 260 \\
\hline $\begin{array}{c}\text { Muayene Süreci (basınç, boyut ve } \\
\text { ağırlık kontrolü) }\end{array}$ & $\begin{array}{c}500.000 \\
\text { tablet }\end{array}$ & & $\mathrm{x}$ & 90 \\
\hline $\begin{array}{c}\text { Tabletlerin Paketleme Makinesine } \\
\text { Aktarılması }\end{array}$ & $\begin{array}{c}500.000 \\
\text { tablet }\end{array}$ & & $\mathrm{x}$ & 21 \\
\hline Ambalajlama Süreci & $\begin{array}{c}500.000 \\
\text { tablet }\end{array}$ & $\mathbf{x}$ & & 234 \\
\hline $\begin{array}{l}\text { Ürünlerin Paket İçerisinde } \\
\text { Paketlenmesi }\end{array}$ & 1 Paket & & $\mathbf{x}$ & 20 \\
\hline $\begin{array}{c}\text { Ürünlerin, Mamul Depolarına } \\
\text { Taşınması }\end{array}$ & 20 Paket & & $\mathbf{x}$ & 14 \\
\hline
\end{tabular}

Yukarıda belirtilen hesaplamalara ait açıklamalar aşağıda yer almaktadır:

Tablet üretiminde gerçekleştirilen faaliyetlerin zamanları hesaplanırken her 500.000 adet tablet üretimi için gerekli süreler dikkate alınmıştır. Çünkü tablet üretimi 500.000'er adetlik üretimler halinde gerçekleştirilmektedir. Yani bir sefer tablet üretiminde 500.000 adet tablet üretilmektedir. Makine ve ekipmanın sterilizasyon süresi her 500.000 adet tablet için 85 dakika iş gücü çalışma süresidir. Hammaddelerin ayrılması ve sınıflandırılması süresi her 500.000 adet tablet için 68 dakika iş gücü çalışma süresidir. Hammaddelerin hazırlık odasına 
gönderilme süresi her 500.000 adet tablet için 20 dakika iş gücü çalışma süresidir. Hammaddelerin karıştırılması ve kurutulması süresi her 500.000 adet tablet için 60 dakika makine çalışma süresidir. Öğütme işlemi süresi her 500.000 adet tablet için 78 dakika makine çalışma süresidir. Preparatın inceleme süresi her 500.000 adet tablet için 41 dakika işgücü çalışma süresidir. Preparatın presleme makinesine gönderilme süresi her 500.000 adet tablet için 20 dakika iş gücü çalı̧̧ma süresidir. Presleme işlemi süresi her 500.000 adet tablet için 260 dakika makine çalı̧şma süresidir. Muayene işlemi süresi her 500.000 adet tablet için 90 dakika işgücü çalışma süresidir. Tabletlerin paketleme makinesine aktarılması süresi her 500.000 adet tablet için 21 dakika işgücü çalışma süresidir. Ambalajlama süresi her 500.000 adet tablet için 234 dakika makine çalı̧̧ma süresidir. İşgücü çalışma süresi esas alınarak ürünlerin paketlenmesi işlemi ise her paket başına 20 dakika sürmektedir. Ürünler mamul depolarına 20 'şer paketler halinde taşındığ 1 için her 20 paketin mamul depolarına taşıma süresi 14 dakika iş gücü çalışma süresidir. Bu adımın devamında ise üretim faaliyetlerinin toplam sürelerinin hesaplanması için zaman denklemlerinin kurulması gerekmektedir. Uygulamada oluşturulan zaman denklemleri aşağıda yer almaktadır:

Tablet üretim faaliyetlerinin aylık toplam süresi $=\mathrm{B}_{1} * \mathrm{X}_{1}+\mathrm{B}_{2} * \mathrm{X}_{1}+\mathrm{B}_{3} * \mathrm{X}_{1}+\mathrm{B}_{4} * \mathrm{X}_{1}+$ $\mathrm{B}_{5} * \mathrm{X}_{1}+\mathrm{B}_{6} * \mathrm{X}_{1}+\mathrm{B}_{7} * \mathrm{X}_{1}+\mathrm{B}_{8} * \mathrm{X}_{1}+\mathrm{B}_{9} * \mathrm{X}_{1}+\mathrm{B}_{10} * \mathrm{X}_{1}+\mathrm{B}_{11} * \mathrm{X} 1+\mathrm{B}_{12} * \mathrm{X}_{2}+\mathrm{B}_{13} * \mathrm{X}_{3}$

$\mathrm{B}_{1}=$ Her 500.000 adet tablet için makine ve ekipmanın sterilizasyon süresi

$\mathrm{B}_{2}=$ Her 500.000 adet tablet için hammaddelerin ayrılması ve sınıflandırılması süresi

$\mathrm{B}_{3}=$ Her 500.000 adet tablet için hammaddelerin hazırlık odasına gönderilme süresi

$\mathrm{B}_{4}=$ Her 500.000 adet tablet için karıştırma ve kurutma işlemi süresi

$\mathrm{B}_{5}=$ Her 500.000 adet tablet için öğütme işlemi süresi

$\mathrm{B}_{6}=$ Her 500.000 adet tablet için preparatın inceleme süresi

$\mathrm{B}_{7}=$ Her 500.000 adet tablet için preparatın presleme makinesine gönderilme süresi

$\mathrm{B}_{8}=$ Her 500.000 adet tablet için presleme işlemi süresi

$\mathrm{B}_{9}=$ Her 500.000 adet tablet için muayene süresi

$\mathrm{B}_{10}=$ Her 500.000 adet tablet için ilaçların paketleme süresi

$\mathrm{B}_{11}=$ Her 500.000 adet tablet için paketlerin taşıma süresi

$\mathrm{B}_{12}=$ Her bir paket için ürünlerin paketlenme süresi

$\mathrm{B}_{13}=$ Her 20 paket için ürünlerin mamul depolarına taşıma süresi

$\mathrm{X}_{1}=1$ ay boyunca 500.000 'er tabletler halinde kaç sefer üretim yapıldı̆̆ 1

$\mathrm{X}_{2}=1$ ay boyunca kullanılan paket sayıs 1 
$\mathrm{X}_{3}=1$ ay boyunca 20 'şer paketler halinde kaç defa taşıma yapıldı̆̆

Zaman denklemlerinin oluşturulmasının ardından tablet üretimi için gerekli faaliyetlerin aylık toplam süreleri, zaman denklemleri kullanılarak aşağıdaki gibi hesaplanmaktadır:

Tablo 10. Tablet Üretimindeki Faaliyetlerin Aylık Toplam Süreleri

\begin{tabular}{|c|c|c|c|c|}
\hline Faaliyet & $\begin{array}{c}\text { Zaman } \\
\text { (B) }\end{array}$ & $\begin{array}{c}\text { Aylık } \\
\text { süreç } \\
\text { sayısı } \\
(\mathbf{X}) \\
\end{array}$ & $\begin{array}{c}\begin{array}{c}\text { Toplam Süre } \\
\text { (dk) }\end{array} \\
(\mathrm{B} * \mathrm{X}) \\
\end{array}$ & Kaynak \\
\hline Makine ve Ekipmanın Sterilizasyonu & 85 & 40.8 & 3.468 & İşçilik \\
\hline $\begin{array}{c}\text { Hammaddelerin Ayrilması ve } \\
\text { Sinıflandırılması }\end{array}$ & 68 & 40.8 & 2.774 & İşçilik \\
\hline $\begin{array}{c}\text { Hammaddelerin Hazırlık Odasına } \\
\text { Gönderilmesi }\end{array}$ & 20 & 40.8 & 816 & İşçilik \\
\hline $\begin{array}{c}\text { Hammaddelerin Makine Tarafindan } \\
\text { Karıştırılması ve Kurut }\end{array}$ & 60 & 40.8 & 2.448 & Makine \\
\hline Öğ̈̈tme İşlemi & 78 & 40.8 & 3.182 & Makine \\
\hline Preparatın (ilacın) İncelenmesi & 41 & 40.8 & $1.672,80$ & İşçilik \\
\hline $\begin{array}{c}\text { Toz Halindeki Preparatın Presleme } \\
\text { Makinesine Aktarılması }\end{array}$ & 20 & 40.8 & 816 & İşçcilik \\
\hline $\begin{array}{l}\text { Presleme İşlemi (toz halindeki preparatın } \\
\text { tablet haline dönüştürülmesi) }\end{array}$ & 260 & 40.8 & 10.608 & Makine \\
\hline $\begin{array}{l}\text { Muayene Süreci (basınç, boyut ve ağırlık } \\
\text { kontrolü) }\end{array}$ & 90 & 40.8 & 3.672 & İşçilik \\
\hline $\begin{array}{c}\text { Tabletlerin Paketleme Makinesine } \\
\text { Aktarılması }\end{array}$ & 21 & 40.8 & 856,80 & İşçilik \\
\hline Ambalajlama Süreci & 234 & 40.8 & $9.547,20$ & Makine \\
\hline Ürünlerin Paket İçerisinde Paketlenmesi & 20 & 3264 & 65.280 & İşçilik \\
\hline Ürünlerin, Mamul Depolarına Taşınmasıdır & 14 & 163.2 & $2.284,80$ & İşçilik \\
\hline
\end{tabular}

2016 yılının Aralık ayında toplam 20.400.000 adet tablet üretimi gerçekleştirilmiştir. Faaliyetler 500.000'er adetlik üretimler halinde belirlendiği için, faaliyetlerin gerçekleştirilme sayısı; toplam üretim miktarının 500.000'e bölünmesi suretiyle hesaplanmaktadır. 20.400.000 adet tablet üretimi / 500.000 table $=40,8$ defa üretim gerçekleştirilmiştir. Faaliyetlerin aylık toplam süreleri hesaplanırken her bir faaliyetin birim süreleri; üretim sefer sayısı olan 40,8 ile çarpılmıştır. Her pakette 6.250 adet tablet bulunmaktadır. Dolayısıyla aylık kullanılan paket sayıs1; toplam üretilen tablet sayısının 6.250'e bölünmesi ile hesaplanmaktadır. 20.400.000 adet tablet üretimi / 6.250 tablet $=3.264$ paket kullanılmıştır. Aylık toplam paketleme süresi; birim paketleme süresinin 3.264 paket ile çarpılması suretiyle hesaplanmıştır. Ürünler işçiler tarafindan 20'şer paketler halinde mamul depolarına taşınmaktadır. Ayda toplam 3.264 paket kullanıldığı için toplam taşıma sayısı şu şekilde hesaplanmaktadır: 3.264 paket / 20'şer paket $=163,2$ adet taşıma. Buna göre aylık toplam taşıma süresi; birim taşıma süresi ile 163,2 sefer taşımanın çarpılması ile bulunmaktadır.

Adım6: $\mathrm{Bu}$ adımda üretimde kullanılan faaliyetlerin genel üretim giderlerinden aldıkları pay hesaplanmaktadır. Tablet üretimindeki faaliyetlerin toplam genel üretim giderlerinden aldıkları pay hesaplanırken, faaliyetlerin aylık toplam süreleri ile dakika başına düşen genel üretim gideri tutarı çarpılmaktadır. 
Tablo 10'dan yararlanılarak tablet üretimindeki faaliyetlerin toplam süreleri; işçilik ve makine olmak üzere ikiye ayrılmıştır. İşçilik ve makine çalışma süreleri şu şekilde hesaplanmaktadır:
İşçilik
Kaynağ 1
Çalışma
(İşlem)
Süresi

$3.468+2.774+816+1.672,80+816+3.672+856,8+65.280+2.284,80=81.640,40$ dakikadir.

Makine Kaynağ 1 Çalışma (İşlem) Süresi $=2.448+3.182+10.608+9.547,20=25.785,20$ dakikadır.

İşçilik ve makine kaynağına ait işlem süreleri hesaplandıktan sonra bu süreler, dakika başına düşen maliyetler ile çarpılarak tablet üretiminde her bir genel üretim giderine düşen toplam maliyet hesaplanmaktadir.

Tablo 11. Tablet Üretiminde Her Bir Genel Üretim Giderine Düşen Payın Hesaplanmas1

\begin{tabular}{|c|c|c|c|c|}
\hline Genel Üretim Giderleri & Kaynak & $\begin{array}{c}\text { Toplam } \\
\text { İşlem } \\
\text { Süresi } \\
\text { (Dk.) } \\
\end{array}$ & $\begin{array}{c}\text { Dk. } \\
\text { Başına } \\
\text { Düssen } \\
\text { Maliyet } \\
\end{array}$ & Toplam Maliyet \\
\hline Ücret ve Maaşlar & İşçilik & $81.640,40$ & 0,07 & $5.785,96$ \\
\hline Yakit Gideri & Makine & $25.785,20$ & 0,06 & $1.448,28$ \\
\hline Bakım Gideri & Makine & $25.785,20$ & 0,09 & $2.416,91$ \\
\hline Taşıma Gideri & İ̀şçilik & $81.640,40$ & 0,01 & 495,59 \\
\hline Amortisman Gideri & Makine & $25.785,20$ & 0,27 & $6.837,99$ \\
\hline İlaç Analiz Gideri & İşçilik & $81.640,40$ & 0,002 & 201,21 \\
\hline $\begin{array}{l}\text { Endirekt Malzeme Gideri } \\
\text { (İşçiler ile ilgili) }\end{array}$ & İşçilik & $81.640,40$ & 0,003 & 236,89 \\
\hline $\begin{array}{c}\text { Diğer Üretim Giderleri (İşçiler } \\
\text { ile ilgili) }\end{array}$ & İşçilik & $81.640,40$ & 0,01 & 662,35 \\
\hline TOPLAM & & & & 18.085,17 \\
\hline
\end{tabular}

ZDFTM yöntemi ile iki farklı mamul grubunun genel üretim giderlerinden aldıkları paylar hesaplandiktan sonra, bu kısımda mamullerin toplam ve birim maliyetleri hesaplanmaktadır. Firmanın hesapladığı maliyet yöntemine ve ZDFTM yöntemine göre, direkt ilk madde ve malzeme maliyetleri aynı olduğu için direkt ilk madde ve malzeme maliyetleri iki yöntem için değişmemektedir. Dolayısıyla hem şurup hem de tabletlerin toplam maliyetleri hesaplanırken firmanın hesapladığı direkt ilk madde ve malzeme maliyetleri aynen alınmıştır. İki yöntem arasındaki tek farklılık, ürünlerin genel üretim giderleri tutarlarından kaynaklanmaktadır. Yukarıdaki hesaplamaların sonucunda üretilen şurupların aylık toplam ve birim maliyetleri aşağıdaki gibi hesaplanmaktadır: 
Tablo 12. Üretilen Şurupların Toplam ve Birim Maliyetleri

\begin{tabular}{|c|c|c|c|}
\hline Açıklama & $\begin{array}{c}\text { Toplam Aylık Maliyet } \\
\mathbf{( \$ )}\end{array}$ & Üretilen Şişe Sayısı & Birim Maliyet (\$) \\
\hline $\begin{array}{c}\text { Direkt Illk Madde } \\
\text { ve Malzeme Gideri }\end{array}$ & 186.669 & 630.000 & 0,296 \\
\hline $\begin{array}{c}\text { Genel Üretim } \\
\text { Gideri }\end{array}$ & 29.570 & 630.000 & 0,046 \\
\hline TOPLAM & $\mathbf{2 1 6 . 2 3 9}$ & $\mathbf{6 3 0 . 0 0 0}$ & $\mathbf{0 , 3 4}$ \\
\hline
\end{tabular}

Yukarıda görüldüğü üzere şurupların toplam maliyeti 216.239 \$'dır. Şurupların birim maliyetleri ise toplam maliyetin üretilen aylık şişe sayısına bölünmesi ile hesaplanmıştır. Buna göre bir şişe şurubun maliyeti yaklaşık olarak 0,34 \$'dır. Firma ürettiği tabletlerin maliyetlerini blister üzerinden hesaplamaktadır. Firmanın uyguladığ 1 maliyet yöntemi ve ZDFTM yönteminin kıyaslanabilmesi için tabletlerin maliyetlerine ait sonuçlar tabletler üzerinden değil, blister üzerinden hesaplanmaktadır. Üretilen blisterlerin aylık toplam ve birim maliyetleri aşağıdaki gibi hesaplanmaktadır:

Tablo 13. Üretilen Blisterlerin Toplam ve Birim Maliyetleri

\begin{tabular}{|c|c|c|c|}
\hline Açıklama & $\begin{array}{c}\text { Toplam Aylı Maliyet } \\
\text { (ID) }\end{array}$ & Üretilen Blister Sayısı & Birim Maliyet (ID) \\
\hline $\begin{array}{c}\text { Direkt İlk Madde } \\
\text { ve Malzeme Gideri }\end{array}$ & $60.302,40$ & 2.040 .000 & 0,030 \\
\hline $\begin{array}{c}\text { Genel Üretim } \\
\text { Gideri }\end{array}$ & $18.085,17$ & 2.040 .000 & 0,009 \\
\hline TOPLAM & $\mathbf{7 8 . 3 8 7 , 5 7}$ & $\mathbf{2 . 0 4 0 . 0 0 0}$ & $\mathbf{0 , 0 4}$ \\
\hline
\end{tabular}

Yukarıda görüldüğü üzere blisterlerin toplam maliyeti 78.387,57 \$'dır. Blisterlerin birim maliyetleri ise toplam maliyetin üretilen aylık blister sayısına bölünmesi ile hesaplanmıştır. Buna göre bir adet blisterin maliyeti yaklaşık olarak 0,04 \$'dır.

\subsection{Bulguların Karşılaştırması}

Zamana dayalı faaliyet tabanlı maliyetleme nedeni genel üretim giderlerinin daha etkin bir şekilde dağıtılmasının sağlanmasıdır. Dolayısıyla ZDFTM ile diğer yöntemler arasında, direkt giderlerin hesaplanması konusunda bir farklılık bulunmaktadır. Bu nedenden dolayı firmanın hesaplama sonuçları ile ZDFTM sonuçları karşılaştırılırken; direkt giderler aynı olduğu için, sadece genel üretim giderleri karşılaştırılmaktadır. Firmanın hesaplamalarına göre mamullere dağıtılan toplam genel üretim gideri (GÜG) ile ZDFTM hesaplamalarına göre mamullere dağıtılan toplam GÜG arasındaki farklılıklar aşağıdaki tabloda gösterilmektedir: 
Tablo 14. Genel Üretim Giderleri Açısından Firmanın Hesaplamaları ile ZDFTM Sonuçları Arasındaki Farklılıklar

\begin{tabular}{|c|c|c|c|}
\hline Ürün Çeşidi & $\begin{array}{c}\text { ZDFTM'ye Göre } \\
\text { GÜG Toplamı (\$) } \\
(\mathbf{a})\end{array}$ & $\begin{array}{c}\text { Firmanın Hesaplamalarına } \\
\text { Göre GÜG Toplamı (\$) } \\
\text { (b) }\end{array}$ & $\begin{array}{c}\text { Toplam GÜG } \\
\text { Arasındaki Fark (\$) } \\
\text { (a-b) }\end{array}$ \\
\hline Şişe (Şurup) & 29.570 & 25.774 & $\mathbf{3 . 7 9 6}$ \\
\hline Blister (Tablet) & 18.085 & 25.774 & $\mathbf{- 7 . 6 8 9}$ \\
\hline $\begin{array}{c}\text { Mamullere Dağttılan } \\
\text { Toplam GÜG }\end{array}$ & $\mathbf{4 7 . 6 5 5}$ & $\mathbf{5 1 . 5 4 8}$ & $\mathbf{- 3 . 8 9 3}$ \\
\hline
\end{tabular}

Firmanın hesaplamalarına göre birim başına düşen genel üretim gideri (GÜG) ile ZDFTM hesaplamalarına göre birim başına düşen GÜG arasındaki farklılıklar ise aşağıdaki tabloda gösterilmektedir:

Tablo 15. Genel Üretim Giderleri Açısından Firmanın Birim Maliyetleri ile ZDFTM Birim Maliyetleri Arasındaki Farklı11klar

\begin{tabular}{|c|c|c|c|}
\hline $\begin{array}{c}\text { Ürün } \\
\text { Çeşidi }\end{array}$ & $\begin{array}{c}\text { ZDFTM'ye Göre Birim } \\
\text { Maliyet (\$) } \\
\text { (a) }\end{array}$ & $\begin{array}{c}\text { Firmanın Hesaplamalarına } \\
\text { Göre Birim Maliyet (\$) } \\
\text { (b) }\end{array}$ & $\begin{array}{c}\text { Birim Maliyetler } \\
\text { Arasındaki Tutar } \\
\text { Farkı (\$) } \\
\text { (a-b) }\end{array}$ \\
\hline $\begin{array}{c}\text { Şişe } \\
\text { (Şurup) }\end{array}$ & 0,0469 & 0,0409 & $\mathbf{0 , 0 0 6 0}$ \\
\hline $\begin{array}{c}\text { Blister } \\
\text { (Tablet) }\end{array}$ & 0,0089 & 0,0126 & $\mathbf{- 0 , 0 0 3 8}$ \\
\hline
\end{tabular}

Yukarıdaki tablolarda görüldüğ̈̈ üzere firmanın hesaplamaları ile ZDFTM yöntemi karşılaştırıldığında ZDFTM yöntemine göre şuruplara daha fazla GÜG dağıtılmıştır. Buna karşın ZDFTM yöntemine göre tabletlere daha az GÜG dağıtılmıştır. Ayrıca, tablo 31'de görüldüğü üzere firmanın hesaplamalarına göre mamullere dağıtılan toplam GÜG toplamı ile ZDFTM yöntemine göre mamullere dağıtılan toplam GÜG arasında 3.893 \$ tutarında bir fark bulunmaktadır. Bu fark aşağıdaki tabloda açıklanmaktadır:

Tablo 16. ZDFTM Yöntemine Göre Genel Üretim Giderleri Dağıtım Tablosu

\begin{tabular}{|c|c|c|}
\hline Açıklama & Tutar (\$) & Yüzde \\
\hline Şuruba Dağıtılan GÜG & 29.570 & $\% 57,36$ \\
\hline Tablete Dağıtılan GÜG & 18.085 & $\% 35,08$ \\
\hline Atıl Kapasiteye Düşen GÜG & $\mathbf{3 . 8 9 3}$ & $\mathbf{\% 7 , 5 6}$ \\
\hline Toplam GÜG & $\mathbf{5 1 . 5 4 8}$ & $\mathbf{\% 1 0 0}$ \\
\hline
\end{tabular}

Yukarıdaki tabloda görüldüğü üzere firmanın mamullere dağıttığı toplam GÜG ile ZDFTM yöntemine göre mamullere dağıtılan toplam GÜG arasındaki fark atıl kapasiteye düşen GÜG toplamıdır. Çalışmada pratik kapasite, teorik kapasitenin \%80'ini olarak kabul edilmiştir. Literatürde, geri kalan \%20'lik kullanılmayan kapasite ise normal kabul edilmektedir. Ancak uygulamalarda \%20'nin üzerinde ilave olarak ortaya çıkan kullanılmayan kapasite, atıl kapasite olarak adlandırılmaktadır. Bu çalışmadaki \%0,56'lık ilave ortaya çıkan kullanılmayan kısım, atıl kapasite olarak kabul edilmektedir. Çalışmaya konu alınan firmada \%20'lik çalışılmayan bir zaman diliminin olması normal kabul 
edilmektedir. Sonuçta ortaya çıkan \%7,56'l1k kısım ise normalin üstünde çalışılmayan ve boşa geçen zamanın olduğunu göstermektedir.

\section{SONUÇ}

$\mathrm{Bu}$ çalışma kapsamında yapılan uygulama, bir ilaç firmasının 2016 yılı Aralık ayı üretim faaliyetleri sonuçları dikkate alınarak gerçekleştirilmiştir. 2016 Aralık ayında fabrikada şurup ve tablet olmak üzere iki tür mamul üretilmektedir. Firmanın mevcut uyguladığı maliyet hesaplama yöntemine göre genel üretim giderleri, herhangi bir dağıtım anahtarı kullanılmadan, şurup ve tablet üretim hatlarına eşit bir biçimde dağıtılmaktadır. Genel üretim giderleri objektif, analitik ve bilimsel yöntemleri esas alan maliyetleme sistemleri kullanılmadan sübjektif olarak dağıtıldığ 1 için, mamullerin maliyetleri gerçeği yansıtmamaktadır. Dolayısıyla firma, genel üretim giderlerinin mamullere daha doğru bir şekilde dağıtılmasını sağlayan çağdaş bir maliyetleme sistemini kullanılmalıdır. Bu şekilde gerçek mamul maliyetlerine ve doğru karlılık rakamlarına ulaşılabilecektir. Zamana Dayalı Faaliyet Tabanlı Maliyetleme (ZDFTM) yöntemi ile zaman esaslı dağıtım anahtarları kullanılarak firmanın genel üretim giderlerinin daha doğru bir şekilde dağıtılacağ düşünülmektedir. Her ne kadar ZDFTM sisteminin kurulumunun firma için maliyetli olmasına karşın ekonomik göstergeler ışığında fayda-maliyet analizi yapıldığında, bu sistemin uygulanmasının firma için doğru bir karar olacağı görülmektedir. ZDFTM sistemi ile mamuller hakkında daha faydalı, detaylı ve gerçek maliyet bilgileri üretilmektedir.

ZDFTM uygulaması kapsamında öncelikle fabrikada 2016 yılının Aralık ayında gerçekleşen, mamullere dağıtılacak genel üretim giderleri çeşitleri ve tutarları belirlenmiştir. Daha sonra fabrika müdürü ile gerçekleştirilen görüşme ile üretimin teorik kapasitesi saptanmıştır. Yine alınan bilgiler neticesinde, üretimin pratik kapasitesinin, teorik kapasitenin \%80'i olduğu tespit edilmiştir. Buradaki pratik kapasiteye, üretimde ortaya çıkan normal zaman kayıplarının çıkarılması ile gerçekte çalışılan zamanın tahmin edilmesi sonucu ulaşılmıştır. Normal zaman kayıpları, çalışanların fabrikaya giriş çıkışlarında harcadıkları süreler, dinlenme zamanları, bakım süreleri gibi kayıplardan oluşmaktadır. Daha sonra, her bir genel üretim gideri toplamı pratik kapasiteye bölünmüş ve birim dakika başına düşen genel üretim gideri hesaplanmıştır. Birim dakika başına düşen genel üretim giderlerinin belirlenmesinin ardından, şurup ve tablet üretimindeki faaliyetler ayrı ayrı tespit edilmiş ve fabrikadaki gözlemlemeler neticesinde bu faaliyetlerin gerçekleşme süreleri dakika cinsinden hesaplanmıştır. Ay boyunca gerçekleşen faaliyetlerin toplam süreleri ile birim dakika başına düşen genel üretim giderleri çarpılarak mamullere düşen genel üretim gideri payı hesaplanmıştır. ZDFTM yöntemine göre yapılan uygulamanın sonuçları ile firmanın maliyet hesaplamalarına ait sonuçlar karşılaştırılmıştır. Direkt maliyetler iki yöntem için de aynı olduğu için sadece genel üretim giderleri sonuçları bakımından, iki yöntem arasındaki farklılıklar aşağıda şu şekilde belirlenmiştir.

Firmanın hesaplamalarına göre bir şişe şuruba düşen genel üretim gideri payı 0,0409 \$ olarak hesaplanmıştır. Ancak ZDFTM'ye göre bir şişe şurubun genel üretim gideri ise 0,0469 \$'dır. Böylece firma hesaplamalarına göre şurubun genel üretim gideri (GÜG) 0,006 \$ daha az hesaplanmaktadır. Firmaya göre blisterin birim genel üretim gideri 0,0126 iken ZDFTM'ye göre 0,0089 \$'dır. Dolayısıyla firma tabletlere 0,0038 \$ daha fazla GÜG yüklemektedir. Görüldügü üzere firmanın mamullere yüklediği GÜG ile ZDFTM'de mamullere yüklenen genel üretim gideri aynı değildir. Bu durum, firmanın mamullere genel üretim giderlerini 
doğru bir şekilde dağıtmadığını göstermektedir. Firmanın uyguladığı maliyet hesaplama yöntemlerine göre toplam GÜG şurup ve tabletlere yarı yarıya dağıtılmaktadır. Bundan dolayı üretilen mamullerin maliyetleri doğru bir şekilde hesaplanmamaktadır. Dolayısıyla öncelikle firma, maliyetlerini daha doğru hesaplayabilmek için çağdaş maliyetleme sistemlerinden birini tercih etmelidir.

ZDFTM sonuçlarına göre şuruplara yüklenen GÜG payı toplam genel üretim giderinin $\% 57,36$ 'sı iken tabletlere yüklenen GÜG payı ise \%35,08'dir. ZDFTM sisteminin faydas1, üretimde ortaya çıkan atıl kapasite yüzdesinin belirlenmesidir. Araştırma sonuçlarına göre GÜG toplamının mamullere yüklenmeyen \%7,56'lik kısmın, atıl kapasiteye ait olduğu görülmektedir. Buradaki atıl kapasite, normalin dı̧̧ında ortaya çıkan zaman kayıplarından ötürü oluşmaktadır. Pratik kapasitede hesaplanan \%20'lik normal zaman kaybına ilave olarak ortaya çıkan $\% 7,56$ 'lik atıl kapasite sebebiyle firma, faaliyetlerde harcanan süreleri gözden geçirerek gereksiz ve boşa geçen zamanları ortadan kaldırmalıdır.

Üretim sürecindeki işlemler incelendiğinde tablet üretiminde presleme işleminin çok uzun zaman aldığı tespit edilmiştir. Bu süreyi kısaltmak için yeni presleme makineleri satın alınarak teknolojik imkanlardan faydalanılabilir. Hem tablet hem de şurup üretimindeki ambalajlama sürelerinin de uzun olduğu görülmektedir. Ambalajlama sürelerini kısaltmak için otomasyondan faydalanılabilir ve üretim hatlarının sayısı artırılabilir. Yine uygulama sonuçları incelendiğinde paketleme sürelerinin de uzun ve maliyetli olduğu görülmektedir. İşletme yönetimi paketleme sürecini iyileştirmek ve maliyetleri düşürmek için gerekli önlemleri almalıdır. Benzer şekilde paketlemede işgücünün yerine makinelerin kullanılması ile paketleme sürelerinin kısaltılabileceği düşünülmektedir. Bununla birlikte, fayda maliyet analizi yapılarak, üretimin tümünde otomasyon sistemine geçilerek üretimde zaman tasarrufuna gidilebilir. Böylece, gereksiz zaman kayıpları elimine edilerek maliyetler düşürülebilecek ve işletmenin karlılığı artırılabilecektir. Dolayısıyla üretim faaliyetlerinde etkinlik ve verimlilik sağlanabilecektir.

\section{KAYNAKLAR}

Cengiz, Emre (2011), "Faaliyet Tabanlı Maliyetleme ve Sürece Dayalı Faaliyet Tabanlı Maliyetleme Arasındaki Farklar-Bir Mobilya Üreticisi Firmada Vaka Çalışması", Muhasebe ve Finansman Dergisi, Nisan, ss. 33-58.

Dejnega, Oleg (2011), "Method Time Driven Activity Based Costing - Literature Review", Journal of Applied Economic Sciences, Cilt VI, Sayı 1(15), pp. 7-15.

Demireli, Cemalettin - Yılmaz, Metin (2013), “'Zamana Dayalı Faaliyet Tabanlı Maliyetleme Yönteminin Stratejik Pazarlama Kararlarına Etkisi”, CBÜ Sosyal Bilimler Dergisi, Cilt: 11, Say1: 2, ss. 294-308.

Everaert, Patricia - Bruggeman, Werner - Sarens, Gerrit - Anderson, Steven R. - Levant, Yves (2008), "Cost Modeling in Logistics Using Time-Driven ABC Experiences From s Wholesaler", International Journal of Physical Distribution \& Logistics Management, Cilt: 38, Sayı: 3, pp. 172-191. 
Hoozee, Sophie - Bruggeman, Werner (2010), “Identifying Operational Improvements During the Design Process of a Time-Driven ABC System: The Role of Collective Worker Participation and Leadership Style', Management Accounting Research, Cilt: 21, Say1: 3, pp. 185-198.

Kaplan, Robert S. - Anderson, Steven R. (2003), “Time-Driven Activity Based Costing”, November.

Kaplan, Robert S. - Anderson, Steven R., (2004), “Time-Driven Activity Based Costing”, Harvard Business Review, Tool Kit, November.

Koşan, Levent (2007), “Maliyet Hesaplamasında Yeni Bir Yaklaşım: Sürece Dayalı Faaliyet Tabanlı Maliyetleme Sistemi', Mali Çözüm Dergisi, Sayı: 84, ss. 155-170.

Köse, Tunç (2010), Sürece Dayalı Yönetim Kapsamında Maliyet Yönetimi, 1.Baskı, Detay Yayınc1lık, Ankara.

Oliveira, J.R. - Oliveira, S.B. (2015), “TDABC Method And Process Management: The Experience Inside Of A Certification Laboratory Of A Research Centre', Review Of Research, Cilt: 4, Sayı: 10, July.

Polat, Levent (2011), "Zaman Sürücülü Faaliyet Tabanlı Maliyetlemenin Bir Sanayi İşletmesinde Uygulanması', Muhasebe ve Finansman Dergisi, Ocak, ss. 126-137.

Szychta, Anna (2010), “Time-Driven Activity-Based Costing in Service Industries”, Reserch Gate, March, 1(67), pp. 49-60.

Yükçü, Süleyman - Gönen, Seçkin (2009), “Zaman Esaslı Faaliyete Dayalı Maliyetleme Yaklaşımının Otomobil Parçaları Üreten Bir İşletmede Uygulanması', Muhasebe ve Denetime Bakış, Nisan, Sayı: 28, ss 19-32. 
